\title{
HIGHLIGHTS OF BRITISH \\ AND GERMAN PROPAGANDA \\ IN THE UNITED STATES, 1939-1941
}

\section{BY JOHN W. OSBORNE}

Mr. OsBORNe, currently the Bevier Fellow in History at Rutgers University, received his $M . A$. degree from Rutgers in 1959.

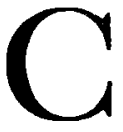

OUNTRIES at war are naturally anxious to secure a favorable attitude toward their cause among the governments and peoples of neutral nations. Germany and Great Britain, antagonists in I939 as in I9I4, were certainly not exceptions to this rule. Although each attempted to achieve different objectives with respect to American opinion, both made a concerted effort at considerable cost. Pamphlets in possession of the Rutgers University Library provide an interesting insight into the methods and techniques used by each side to present its case to the American public from 1939 to $194 \mathrm{I}$.

The dismal failure of German attempts to influence in a positive manner American public opinion prior to the entry of the United States into World War $\mathrm{I}^{1}$ was frankly acknowledged in Nazi Germany. Therefore, considerable time and money were expended to endeavor to achieve a more favorable American attitude toward Germany during the last few years before midsummer I94I, when the German consulates were closed by order of the United States government. The problems in this respect were formidable: the traditional captivation of the minds of literate Americans by England, based upon a common political, legal, and literary heritage, was probably as great in I939 as it was in 1914. On the other hand, the lack of sympathy for the militarism of the Kaiser's Germany had been replaced by an active disgust among almost all articulate Americans for the pattern of society which the Nazis had developed since 1933 .

\footnotetext{
${ }^{1}$ See Propaganda Technique in the First World War by Harold D. Lasswell (New York, Alfred A. Knopf, 1927). Also Walter Millis's controversial Road to War, America, 1914-rgr7 (Boston, Houghton Miflin Company, 1935).
} 
The same feeling existed among many other Americans, who were, as a rule, scarcely interested in foreign affairs.

Thus, anti-German sentiment was deeper and more widespread in I 939 than in I9I4. This situation was scarcely mitigated by the isolationism of the majority of Americans. This isolationist feeling took the form of a general disenchantment with foreign adventures, rather than specific resentment directed at one particular country. However, the rulers of Nazi Germany were not backward in their ability to manipulate public opinion in their own country, and they had achieved a certain measure of success elsewhere on the Continent. Perhaps no nation was as equipped as she to arrest hostile sentiment. ${ }^{2}$

The focus of German propaganda during this period was the wellequipped German Library of Information in New York City. Founded in 1936, the Library contained, in addition to the usual current periodicals and newspapers, a reading room with several thousand books, a sound library which boasted ro,000 records, and a large collection of reference materials. The principal publication of the Library was Facts in Review, a weekly bulletin started in August, 1939, whose purpose was "to outline facts about Germany and her attitude toward world affairs." It was distributed to anyone who might conceivably have any influence over public opinion. ${ }^{4}$ There were printed as well a considerable number of diversified and often elaborate pamphlets and brochures showing various aspects of German civilization; and, of course, German documents relating to international affairs were published in book or pamphlet form as is the custom with agencies of major countries charged with the propagation of ideas.

Facts in Review provides an insight into the methods of German propaganda. The earliest copy available at the Rutgers University Library is dated January 6, I940. It contains excerpts from Hitler's New Year's message, an attack upon British imperialism (this was a major theme in subsequent issues), a discussion of the German White Book and the British Blue Book, and an analysis of

${ }^{2}$ For a history of American foreign relations during the period under discussion, see William L. Langer and S. Everett Gleason, Challenge To Isolation, 1937-r940 (New York, Harper and Brothers, I952), and The Undeclared War, 1940-194I (New York, Harper and Brothers, 1953).

${ }^{3}$ Facts in Review (June Io, 1940), p. 244.

${ }^{4}$ Harold Lavine and James Wechsler, War Propaganda and the United States (New Haven, Yale University Press, 1940), p. 248. 
German population problems, emphasizing government attempts to achieve a higher birth rate (the February 5, I940, issue features a complaint that $87,000,000$ Germans must subsist on 264,300 square miles). The last issue in the Library, dated June 7, 194I, nine days before all German consulates were closed by order of the United States government, offered illustrated articles on the Teutonic Knights, war time sports, industry and rural electrification, in addition to the usual news bulletins. The two issues mirror a gradual shift in emphasis over a period of eighteen months from analyses of political data toward an attempt to interpret contemporary German civilization and to display those aspects of German history and culture most apt to meet with a favorable response from Americans.

The enormous problems which faced the Germans in their efforts to sway American opinion are evident upon even a casual examination of Facts in Review. There comes to mind at this point a Low cartoon of the late thirties showing Goebbels playing away on a huge organ, while a Britisher relied upon a tiny portable victrola. The situation was supposed to be analogous to the disparity between the propaganda apparatus of the two countries. Nevertheless, however massive the German organ, it lacked certain vital chords, which were essential for making a real impression in the United States. These chords, representative institutions, language and literature, and the English common law, shared by both England and America, were played upon with great skill by the British. Their absence was a great handicap to the Germans, and no amount of pictures of the German home of the future or recondite articles about what Germany intended to do with reference to the international gold problem could compensate.

The transition from political analyses, documentary defenses of German actions, and attacks upon British colonial policy, to material of a cultural nature (interpreted in the broadest sense) was not complete. For example, in the spring of I94I, following the Nazi invasion of the Balkans, there was an attempted justification by means of reprinting German notes to the Yugoslav and Greek governments and Hitler's orders to the German troops. This followed the pattern set by Facts in Review after earlier aggressions. Hitler's speeches, incidentally, were frequently printed in their entirety, sometimes filling an entire issue. The reason given was that American students of foreign affairs were unable either to hear or to read 
the complete speeches. A schedule of German short wave broadcasts to North America, excerpts from domestic news reports, and a column called "Facts in Brief" were features of almost every issue. Some of the material in this column is poignant. Bland announcements about settlement of border and minority questions with $\mathrm{Ru}$ mania and Hungary and the formation of a Kingdom of Croatia under Ante Pavelic, with the Ustasha as the "bearer of the national will," imply tragedy for thousands of people.

German propaganda, as revealed in Facts in Review, scarcely touched upon political matters relating to America. The tenor of the few brief references seems to indicate an attempt to convey an attitude of mutual forbearance toward the domestic political system of each nation. This was reinforced by reprints of newspaper interviews which Hitler and Goering had granted to American newspaper correspondents, in which each disclaimed any aggressive ambitions toward the Americas. There was little in the way of an attempt to counteract the generally unfavorable impression of the Nazi leaders in this country. Nor, apart from blanket denials of "atrocity stories," was there much defense of the German treatment of minority groups. This whole question was almost ignored, although text and picture reports of the German occupation of Denmark and Norway, the Low Countries, and France appear frequently. At first this represented mere military boasting; but this line was replaced by one featuring jolly pictures purporting to show the camaraderie between civilians and the German armed forces. It was obviously directed at those Americans with families in the affected countries.

The fascination which German industrial prowess had long exercised over many Americans was exploited by Facts in Review. However, in addition to descriptions of technical progress in the form of new methods, and pictures of massive machinery, there was considerable emphasis upon the worker's role in the new German society. The point of several articles was that a new spirit existed within industry, thanks to inspired Nazi leadership, "that fused Industry and Labor into a new unit." Alleged improvement of wages and conditions in factories and homes was discussed at great length in sev-

${ }^{5}$ Facts in Review (September I6, 1940), p. 455, and (June 7, 1941), p. 325.

${ }^{6}$ Facts in Review (April 2, 1941), p. 147. 
eral issues and, indeed, social questions relating to industry were dealt with in detail.

Even at first reading many of the claims of social progress made under Hitler would seem fatuous to many Americans, and since all such writings imply criticism of the economic system characteristic of the United States, one wonders at this peculiar bias. Descriptions of the benefits which the worker was supposedly receiving as a result of making "the industrial plant, including every member from owner and manager to the humblest worker, an organic part of the great new Commonwealth," "' would not evoke much in the way of a favorable response from Americans, already firmly committed to an anti-Nazi position, and it is difficult to imagine American businessmen being enthusiastic over pictures of spotless company cafeterias, or garden apartments and swimming pools for workersall achieved by "cooperation" between government and industry. More information about lightweight machinery, turbines, alloys, etc., might have served the cause better.

This personal approach is evident elsewhere in Facts in Reviev, permeating many discussions of a literary or artistic nature. The view was advanced that the loftiest expressions of German culture were now being made available to the masses for the first time. Concerts featuring Beethoven and lectures on the fine arts were as much a part of the Kraft durch Freude movement as hiking and mass gymnastics. The image created of a well disciplined proletariat marching to the concert hall to hear Bach or Palestrina is not without its humor.

The degradation of the arts under Hitler is revealed by an illustrated article entitled "Degeneration and a Modern Renaissance." Here a frank defense was offered for the extirpation of modern painting and sculpture from the museums of the Third Reich. This explanation, featuring selections from speeches by Hitler, was a rare attempt to justify an unpopular Nazi domestic practice. The theory and expression of modern art, as demonstrated by contributions of Germans in the I920's, received an unmeasured castigation for its failure to remember "the eternal truth that no art can live that is not rooted in its own soil," and for the replacement of "common sense and instinct" by "a rootless and exagger-

7 Ibid., pp. $146-7$.

8 Facts in Reviea (June 3, 1940), pp. 228-33. 
ated intellectualism." Approved art, as depicted throughout this refreshingly candid article, and in other issues of Facts in Review, reveals an abundance of the banal, athletic realism so common in totalitarian countries-although some of the architecture is not without a certain massive elegance. On the whole, it is just what might appeal to the man in the street in Germany and elsewhere; hence, it is not without merit when considered in the context of the material with which the present article deals.

Catering to American sentiments respecting religion and its role within society, the Germans endeavored to show in numerous articles that true religious liberty existed within the Reich. Protestant and Catholic clergymen lent their assistance to prove that the new German state was not incompatible with religion, and the relations of church and state were discussed frequently. Photographs of new church buildings supplemented the text-pictorial evidence of the alleged concord. This is an important theme and the Germans generally handled it well, despite a curious tendency to discuss Christian festivals as derivatives of Teutonic pagan rites. It might be mentioned that there was scarcely any mention of the Jewish people of Germany or of the occupied countries. In the Rutgers collection there are just two references-both to Polish Jews, who, according to James T. Nicholson, President of the Junior Red Cross, were not being persecuted by being moved to certain areas within Poland. "It is simply a solution to the minority problem," explained Mr. Nicholson. "As Carlyle might have said, "Indeed it is!"

Frequent features dealing with the function of radio, sport, and the films in German life further this personal approach at the expense of abstract analyses. Science and technology, certain to appeal to an American audience, are dealt with primarily through brief descriptions of inventions, the wartime use of synthetics, and medical progress. The confident, oversimplified tone assumed in dealing with these topics provokes irritation and skepticism. Perhaps the most egregious example of this is contained in a description of a cancer therapy mechanism, which, according to the article, was to help a patient "throw off" the disease. ${ }^{10}$

As the relations between Nazi Germany and the United States

${ }^{9}$ Facts in Review (May 27,1940 ), p. 217.

${ }^{10}$ Ibid. 
deteriorated, Facts in Review became more elaborate and more skilled in its presentation. There was an attempt to communicate an impression that the German rulers were concerned about the problem of preserving traditional German culture in the midst of war and the demands of a complex industrial society. Two or three issues published in the spring of $194 \mathrm{I}$ show evidence of intelligent and careful preparation. They may be considered as outstanding examples of German propaganda, attempting to convey a juxtaposition of military triumph, intellectual and spiritual enlightenment, and social dynamism.

However, since they pursued the negative goals of endeavoring to keep America neutral and to restrict American aid to the Allies, ${ }^{11}$ the Germans exhibited a defensive posture; and paradoxically, the military successes of the Nazis increased their difficulties in this country, whereas the British skillfully made use of disaster to strengthen their position. Favored with the knowledge that their cause enjoyed at least the passive support of a large majority of the American people, Britain's propaganda experts had correspondingly greater ambitions than their German equivalents, and they were concerned with evoking the maximum response in their efforts to secure American aid.

With regard to style, the major difference between British and German propaganda is the rigidity which characterizes the German use of language. This formality of expression, which renders Facts in Revierw awkward and pedantic even when dealing with simple topics, is generally missing in the British publications, which are graced with a more fluent expression. In contrast to the Germans, the British show themselves to be masters at relating the revealing personal experience or the homey anecdote.

As in World War I, Britain could secure for propaganda purposes the services of an impressive number of its distinguished men, some of whom were very well known on this side of the Atlantic. Among the articles contained in publications in possession of the Rutgers University Library are some attributed to figures such as philosopher C.E.M. Joad, historian G. M. Young, poet Alfred Noyes, and

${ }^{11}$ Lavine and Wechsler, op. cit., p. 243. As yet there has not been published a definitive work dealing with the impact of Allied and Axis propaganda upon American opinion from September, 1939, to December, I941. This book has among its shortcomings the obvious one of being printed in June, 1940. 
Josiah Wedgwood, Member of Parliament. After the retirement of Sir Angus Fletcher in August, 194I, the Director of the British Library of Information was the noted historian, C. K. Webster. Allan Nevins was among the first of many Americans to write articles interpreting the British war effort for American readers. It is probably superfluous to mention that neither at home nor abroad could the Germans call upon widely known advocates of their own cause. ${ }^{12}$

The collection of the Rutgers University Library includes issues of Britain To-Day, a bi-weekly illustrated booklet which was printed in England on cheap paper and contained as a rule four short, unrelated articles. There are also numerous copies of Bulletins from Britain, an unsophisticated weekly leaflet of eight pages, devoted mainly to brief announcements of current events and shortened articles from the British press. Occasionally there would be included in the Bulletin a supplement devoted to a specific topic-a government in exile, or perhaps a description of library losses in England due to bombing. All phases of contemporary British life were discussed in a discursive manner, although with some emphasis on the effect of war upon the life of average citizens. "The Community and the Soldier" (October I 8, I 940), "Women Making Munitions" (November I 5, 1940), and "The Health of War Workers" (December I3, 1940) are representative of the articles in Britain To-Day.

After the American entry into the war, publications emanating from the British Library of Information stressed the contributions which Britain was making to the common war effort. A Reader's Digest-sized monthly of 68 pages, Britain, begun in I 942, demonstrated increasing technical polish as well as a greater variety of contributions. Subscriptions to this magazine sold for \$I a year (publications previously mentioned were distributed free), and in a typical issue readers were provided with articles by Harold Nicholson, Ernest Barker, John Masefield, Geoffrey Faber, and about twenty others. Most of these authors were British, but there were a few Americans as well. Included in Britain were four pages of good photographs and numerous cartoons reprinted from British and American newspapers. A considerable variety of small leaflets de-

\footnotetext{
${ }^{12}$ It is not the purpose of this article to discuss the role of speakers or organizations such as the English Speaking Union, in which the Germans were at an even greater disadvantage.
} 
voted to one particular topic were issued. These usually stressed the armed services or the home front, although many were reprints of speeches by Churchill or other government figures and also discussions of Commonwealth affairs.

Not being faced with the necessity of continually justifying themselves, the British were able to relax, admit past errors, and discuss imperfections in their society and schemes for improving it. The latter is the most salient feature of the British publications as a whole, and in the period under discussion there were more articles dealing with postwar planning than any other subject. These articles were not written primarily in the narrow context of rebuilding damaged factories or of schemes to recapture the world market, but rather consist of projected efforts to replace slum houses destroyed by bombing with clean, airy dwellings, with public health, and with education. These themes reflect the ability of the British in emphasizing the role of the individual citizen. Here, the Germans, with their stress upon perpetual triumph, were deficient.

The titles of several articles in Britain To-Day are suggestive: "Dickens Still Lives" (August 22, I 95 I), "The English Joke" (June 27, I94I), "The Man with the Badge" (July I I, I 94I). These are short, lively and insubstantial stories, yet are apt to create a more favorable impression upon the layman than discussions, for example, of the careers of Goethe or Schiller. Of course, the Germans had no Dickens to dust off and bring up to date, but this only confirms the British advantage. However, it would be a mistake to suppose that heavy emphasis was placed upon either history or letters; that the great heroes of English liberty and literature were summoned to do their bit by reminding Americans of the mutual heritage. Not the peril of the Armada, but the peril of the Luftwaffe; not the stage of Shakespeare's Globe, but the stage of the strolling Pilgrim players comes alive in these pages. Reading them, one is made aware of what it means to the citizens of a great nation to be caught up in the grasp of total war.

The spirit of the Anglo-American heritage permeates the pages of the British publications, but it is expressed in a subtle, indirect fashion that contrasts vividly with the rather strident claims of the Germans. For this reason a more explicit approach by the British, designed to overcome chauvinistic teaching of American history and government in primary and high schools, might have been less ef- 
fective. It is possible that a greater stress upon this subject could have diluted the total impression which these publications leave with the reader - that of a wonderful sense of community existing within Anglo-American society.

"Long before Britain was assured of unstinted material help from the United States she was aware of the community of feeling between herself and that nation in regard to the essentials of government and international relations." ${ }^{13}$ This statement demonstrates the unequal nature of the contest. Together with the fears engendered by the spread of Nazi power over Europe, a situation was created which rendered nugatory the sturdy efforts of experienced propagandists to achieve the relatively modest goals of the Germans.

${ }^{13}$ Britain To-Day (January 23, 194I), p. 2. 